\title{
Serial discontinuity along the Descoberto River Basin, Central Brazil
}

Descontinuidade serial ao longo da bacia do rio Descoberto, Brasil Central

Weliton José da Silva ${ }^{1}$, Sirlene Aparecida Felisberto ${ }^{2}$,

Claudia Padovesi Fonseca ${ }^{3}$ and Maria das Graças Machado de Souza ${ }^{4}$

${ }^{1}$ Programa de Pós-graduação em Botânica, Museu Nacional, Universidade Federal do Rio de Janeiro - MN/UFRJ, Rio de Janeiro, RJ, Brazil

e-mail: welitondasilva@yahoo.com.br

${ }^{2}$ Instituto de Ciências Biológicas, Universidade Federal de Goiás - UFG, Goiânia, GO, Brazil e-mail: sirfe@hotmail.com

${ }^{3}$ Departamento de Ecologia, Instituto de Ciências Biológicas, Universidade de Brasília - UnB, Brasília, DF, Brazil

e-mail: padovesif@yahoo.fr

${ }^{4}$ Departamento de Botânica, Instituto de Ciências Biológicas, Universidade de Brasília - UnB, Brasília, DF, Brazil

e-mail: gmachado@unb.br

\begin{abstract}
Aim: The Descoberto Basin was studied as a discontinuous ecological system through one seasonal cycle (about one year), at 13 sampling sites; Methods: The connectivity was analyzed in relation to environmental and limnological characteristics along the length of the Descoberto River, and the variables that most influenced the different sampling sites were determined; Results: Sites K and L, located upstream and downstream of the entrance of the Melchior River, respectively, differed most in physical and chemical parameters. A Principal Components Analysis demonstrated that the system was more influenced spatially than temporally, with $74.57 \%$ of accumulated variance accounted for by the first two axes. High values of chloride, chlorophyll- $a$, BOD5, total phosphorus, and total organic carbon, as well as low dissolved-oxygen concentrations separated sites $\mathrm{L}$ and $\mathrm{M}$ from the others. Winter and spring were the seasons in which most parameters showed significant differences among the sites; Conclusions: The construction of the dam and waste discharge act as discontinuity factors affecting the referred system, mainly at middle region and lower patch, between the sites $\mathrm{K}$ and L. Besides the construction of the reservoir, the Melchior River, an extremely impacted system, affects the Descoberto River downstream from its entry. Important changes in water quality occur in the lower basin, especially downstream of the Descoberto Reservoir, with significant increases in nutrient concentrations, suspended solids, turbidity, and chlorophyll $a$, and therefore a decrease in water clarity.
\end{abstract}

Keywords: connectivity in rivers, discontinuity, reservoir, anthropogenic influence, tropical aquatic systems.

Resumo: Objetivo: A bacia do rio Descoberto foi estudada como um sistema descontínuo através de um ciclo sazonal (um ano) em 13 estaçôes amostrais; Métodos: A conectividade foi analisada em relaçáo a características ambientais e limnológicas ao longo eixo longitudinal do rio Descoberto e as variáveis que mais influenciaram as diferentes estaçōes amostrais foram determinadas; Resultados: As estações $\mathrm{K}$ e L, localizadas a montante e jusante da entrada do rio Melchior, respectivamente, diferiram mais quanto aos parâmetros físicos e químicos da água. Uma análise de componentes principais (PCA) demonstrou que o sistema foi mais influenciado espacialmente que temporalmente, com $74,57 \%$ da variância total acumulada nos dois primeiros eixos. Altos valores de cloreto, clorofila a, DBO5, fósforo total e carbono orgânico total, tanto quanto baixas concentraçóes de oxigênio dissolvido separaram as estaçôes L e M das demais. Inverno e primavera foram estaçóes nas quais a maioria dos parâmetros apresentou diferenças significativas entre as estaçôes; Conclusóes: A construção do reservatório e descargas de esgoto atuaram como fatores de descontinuidade afetando o referido sistema, 
principalmente no trecho médio do rio e no trecho inferior, entre estações $\mathrm{K}$ e L. O rio Melchior, a partir de sua entrada, afetou o rio Descoberto. Importantes mudanças na qualidade de água ocorreram na bacia especialmente a jusante do reservatório, com aumentos significativos de nutrientes, sólidos suspensos, turbidez e clorofila a e, portanto, na diminuição da transparência da água.

Palavras-chave: conectividade de rios, descontinuidade, reservatório, influência antrópica, sistemas aquáticos tropicais.

\section{Introduction}

Under natural conditions, lotic systems show continuous gradients of physical and chemical factors that result in a "continuum of biological adjustments" (Vannote et al., 1980). The interruption of this continuum may occur by anthropogenic actions such as construction of reservoirs and discharge of waste from any source (Straškraba et al., 1993; Malmqvist and Rundle, 2002). This phenomenon is expressed by the serial discontinuity concept (Ward and Stanford, 1983, 1995; Stanford and Ward, 2001), according to which dams and pollution are the main cause of interruption of the river continuum.

Among the approaches used in recent years to evaluate the continuity of the systems is the physical and chemical characterization (Cushing et al., 1983; Lorenz et al., 1997; Marques et al., 2003), which assesses the water quality and management of these resources for general use. This characterization describes the dynamics of the abiotic factors, which influence the stability of the aquatic communities. Some of these factors are essential to maintain the metabolism of the entire ecosystem (Carmouze, 1994) catalyzing or functioning as sources or products of photosynthetic reactions of aquatic producers (e.g., nutrient concentrations, dissolved oxygen, and organic carbon) (Baker et al., 2000; Homewood and Purdie, 2004) and/or contributing to the availability of compounds of the respiration process at higher trophic levels (e.g., pH, water temperature) (Regier et al., 1990; Reich and Oleksyn, 2004; Paradis et al., 2008; Araújo et al., 2009).

Some studies in tropical environments have treated the river continuum concept and serial discontinuity concept for riverscapes, mainly with respect to the biotic communities (e.g., Sreekantha et al., 2008; Araújo et al., 2009; Doi, 2009). However, most existing studies refer to the temperate regions of the Northern Hemisphere, as observed by these concepts (Vannote et al., 1980; Ward and Stanford, 1983, 1995; Stanford and Ward, 2001). Other tropical environments have some natural peculiarities (e.g., shallow lakes and temporary meanders, floodplains) that may redefine well-stated theories (e.g., the river continuum concept). An example of this is the flood-pulse concept (Junk et al., 1989) which applies to many South American rivers. In central-western Brazil, studies on the continuity (connectivity and/ or discontinuity) of riverscapes (typical tropical environments) are still incipient.

The Descoberto River is an important body of water in the Federal District in central-western Brazil. Its basin is the largest in this region, with a high potential for agricultural exploitation, water supply, and recreation (Valadão, 1996; Brito, 1999; Falcomer, 2001; Ribeiro, 2001; Cardoso, 2002). The Descoberto River Basin is supplies $70 \%$ of the water of the area (Carmo et al., 2005). Despite its importance, studies of this system are still incipient (Carmo et al., 2005). The basin contains recreation areas, the Descoberto Dam, waste-discharge points, riverbed gravel-mining operations, ranches, agriculture with accompanying pesticide use and, uncontrolled occupation of the riverbanks (Rego, 1997).

Therefore, our hypothesis is that the Descoberto River Basin is a serially discontinuous system. Here, we aimed to analyze the connectivity between sample sites along the longitudinal axis of the Descoberto River, to describe limnological aspects of 13 lotic environments of the basin during four seasons, and to determine which ecological variables most influenced these environments.

\section{Material and Methods}

\subsection{Study area description}

The Descoberto River is located in the Paraná River Basin in the western part of the Federal District (DF) and partly in the state of Goiás (GO); of its $950 \mathrm{~km}^{2}$ area, $895.5 \mathrm{~km}^{2}$ lies within the DF (Valadão, 1996; Carmo et al., 2005). The Descoberto is a fourth-order stream and has its source in the confluence of the Barrocão and Capão da Onça streams $\left(15^{\circ} 37^{\prime} \mathrm{S} ; 48^{\circ} 10^{\prime} \mathrm{W}\right)$ (Figure 1). The 
riparian forestis more preserved along the Barrocão Stream than Capão da Onça. In this last system, so many areas destined to the agricultural practice can be observed. In this case, the production of groceries are most predominat. The river was dammed at $15^{\circ} 47^{\prime} \mathrm{S}$ and $48^{\circ} 11^{\prime}$ W. The Descoberto Reservoir is $15 \mathrm{~km}^{2}$ in surface area, 8-22 $\mathrm{m}$ deep, and has a volume of $120 \mathrm{~km}^{3}$. Thus, the course of the Descoberto River now includes both riverine (lotic) and lacustrine (lentic) stretches.

Downstream from the reservoir, the river still flows freely for $28 \mathrm{~km}$ until the main affluent, the Melchior River, enters at $15^{\circ} 56^{\prime} \mathrm{S}$; $48^{\circ} 15^{\prime} \mathrm{W}$ (Ribeiro, 2001). This affluent flows through preserved areas and also the DF region of highest demographic density (Águas Claras, Ceilândia, Samambaia, and Taguatinga). In this densely populated region, the Melchior River suffers extreme impacts, receiving wastewater from domestic and hospital sources and it is, apparently, the only place where the basin receive this kind of polution.

The Descoberto River Basin is seated on rocks of the Paranoá Group, and its pedological formations include Yellow, Red, and Dark-red Latosol, some occurrences of Cambisol, and to a lesser extent Hydromorphic soil (Silva, 2003). The climate is Tropical Savannas (Aw) according to the Köppen classification (CODEPLAN, 1984).

\subsection{Sampling data}

Thirteen sites were selected along the Descoberto Basin, in lotic environments (Table 1). The samples were taken at the subsurface, biweekly between March 2003 and April 2004.

The $\mathrm{pH}$, turbidity, electrical conductivity, and water temperature were measured in loco by means of a water multi-analyzer (HORIBA U-21). Water samples were collected for laboratory measurement of suspended solids (SS), dissolved oxygen concentration (DO), chemical oxygen demand (COD), five-day biochemical oxygen demand (BOD5), total phosphorus concentration (TP), orthophosphate or reactive phosphate (RP), ammonium ion concentrate, nitrate $\left(\mathrm{NO}^{-}\right)$, nitrite (NO2-), fecal coliforms (ColFec), total coliforms (ColTot), chlorophyll $a$, chloride, and total organic carbon (TOC). The sampling and analyses were based on APHA (1995).

Rainfall data and air temperature were provided by INMET (Instituto Nacional de Meteorologia), for a station located $28 \mathrm{~km}$ from the Descoberto Basin (15 $47^{\prime} \mathrm{S}$; $\left.47^{\circ} 56^{\prime} \mathrm{W}\right)$.

\subsection{Presentation and data analysis}

For spatial analysis the different samples along the time was considered replicates of each site (i.e. 24 replicates per site). On the other hand, for seasonal analysis the samples collected into the period were used as replicates (i.e. eight replicates for site). Kolmorov-Smirnov and Bartlett Tests were carried out to verify if the variables satisfied the assumptions of normality and homoscedasticity, respectively, and were performed through the program Statistica 7.1 (StatSoft, 2005). Considering that the results of these tests did not satisfy these assumptions, the Kruskal-Wallis Test was applied to verify if there were significant differences $(\alpha=0.05)$ among the data for sites (24 replicates per site). When such differences were observed, Dunn's Test was carried out to verify between which pair of sites the differences occurred. This test was performed by BioEstat 5.0 software (Ayres et al., 2007).

Table 1. Coordinates and description of sampling sites along Descoberto River Basin.

\begin{tabular}{|c|c|c|}
\hline Site & Description & Coordinates \\
\hline A & Barrocão Stream & 15037'51"S; 4810’37”W \\
\hline B & Capão da Onça Stream & 15038'28"S; 481'54"W \\
\hline C & Descoberto River, upstream from the Descoberto Reservoir & 15042'30"S; 48⒈'01"W \\
\hline $\mathrm{D}$ & Chapadinha Stream & 15042'02"S; 4812'09”W \\
\hline E & Olaria Stream & 15042'34"S; 4811'56"W \\
\hline $\mathrm{F}$ & Rodeador Stream & $15^{\circ} 43^{\prime} 33,5^{\prime \prime S} ; 48^{\circ} 10^{\prime} 08^{\prime \prime W}$ \\
\hline G & Capão comprido Stream & 15044'50"S; 4809'44"W \\
\hline $\mathrm{H}$ & Pedras Stream & 1545'42"S; 4809'31"W \\
\hline I & Descoberto River, immediatly dowstream from Descoberto Reservoir & 15046'52"S; 4813'56"W \\
\hline $\mathrm{J}$ & Descoberto River, near fee fishing & 15052'07"S; 481'ㄴ'W \\
\hline $\mathrm{K}$ & Descoberto River, upstream Melchior River & $15^{\circ} 55^{\prime} 52^{\prime \prime} \mathrm{S} ; 48^{\circ} 16^{\prime} 29^{\prime \prime} \mathrm{W}$ \\
\hline L & Descoberto River, "Sete curvas" & 1603'49"S; 4816'39"W \\
\hline M & Melchior River, near Samambaia Station Sewage Treatment & $15^{\circ} 51^{\prime} 15^{\prime \prime} \mathrm{S} ; 48^{\circ} 09^{\prime} 00^{\prime \prime} \mathrm{W}$ \\
\hline
\end{tabular}


Spearman's Correlation was calculated for the data on chemical and physical variables and biological variables to verify what parameters most influenced the biotic results. The relationships among the sequenced sites were also measured through Spearman's Correlation. These analyses allowed us to evaluate the system continuity, associated with the tests of comparison between

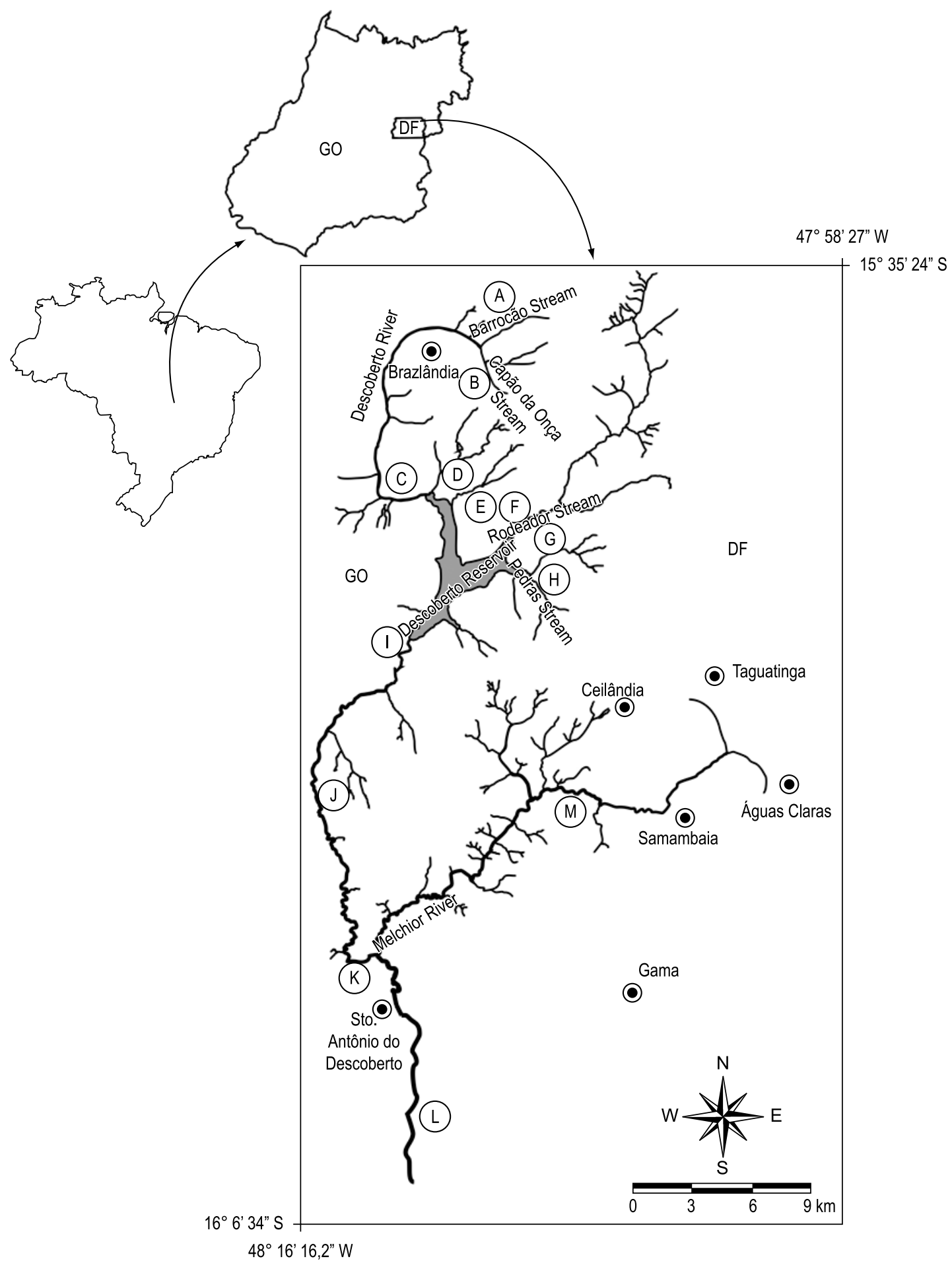

Figure 1. Sampling sites along the Descoberto River Basin (a) Barrocão Stream; b) Capão da Onça Stream; c) Descoberto River, upstream from the Descoberto Reservoir; d) Chapadinha Stream; e) Olaria Stream; f) Rodeador Stream; g) Capão Comprido Stream; h) Pedras Stream; i) Descoberto River, immediatly dowstream from Descoberto Reservoir; j) Descoberto River, near fee fishing; k) Descoberto River, upstream Melchior River; l) Descoberto River, "Sete curvas"; m) Melchior River, near Samambaia Station Sewage Treatment). 
sequential sites (Dunn). These matrices were performed by Statistica 7.1 (StatSoft, 2005).

A Principal Components Analysis (PCA) was applied to reduce the data dimensionality through linear combinations of the values for the 16 variables, using the program PC-ORD (McCune and Mefford, 1997). The data for each physical and chemical variable were log-transformed $[\log (n+1)]$, with $n$ equal to the value of the variable in question, to normalize the data. For the interpretation of the PCA results, axes were used with eigenvalues greater than the Broken-Stick model, suggested by Jackson (1993) as a consistent evaluation to determine the appropriate number of components for data interpretation.

The system continuity and spatial closeness were tested for the following pairs of sites: $\mathrm{A}$ and $\mathrm{C} ; \mathrm{B}$ and $\mathrm{C}$; $\mathrm{C}$ and I; D and I; F and I; F and I; G and I; H and I; I and J; J and K; K and L; and $\mathrm{M}$ and L.

\section{Results}

\subsection{Spatial and temporal characterization}

Two seasonal periods of rainfall occurred: a dry season, from May to October 2004, with no rainfall in June and July 2004; and a wet season, from November 2003 to April 2004, with the highest monthly mean in February 2004 (14.56 mm) (Figure 2). Water temperature ranged between $14{ }^{\circ} \mathrm{C}$ (Winter) and $31{ }^{\circ} \mathrm{C}$ (Summer) in the
Basin, and site L showed the highest annual mean $\left(26.41^{\circ} \mathrm{C}\right)$.

The means of turbidity (Figure 3a) and suspended solids (Figure $3 \mathrm{~b}$ ) were highest at site $\mathrm{M}$, as did $\mathrm{pH}$ (Figure 3c), conductivity (Figure 3d), chloride (Figure $3 \mathrm{e}$ ), and concentrations of the following nutrients: total phosphorus (Figure 3f), nitrate (Figure 3h), and ammonium ions (Figure 3i). Only orthophosphate (Figure 3g) and nitrite (Figure 3j) did not show the same pattern, with the highest values at sites $\mathrm{D}$ and $\mathrm{L}$ respectively.

COD (Figure 4a) and BOD5 (Figure 4b) were also highest at site $\mathrm{M}$, where DO was lowest (Figure 4c). The fecal and total coliform values were highest in March 2004 at site M $\left(2.42 .10^{18} \mathrm{cel} / 100 \mathrm{ml}\right.$ for both variables). For chlorophyll- $a$ the highest value was observed at site $\mathrm{L}$, and the highest means at site M (Figure 4d). The system was more influenced spatially than temporally, as observed on PCA axes 1 and 2 , respectively. The variable values accounted for $74.57 \%$ of the variance accumulated on the first two axes (63.53 and $11.04 \%$, respectively) (Table 2). The highest values of chloride, chlorophyll- $a$, BOD5, TP, and TOC (positively) as well as the lowest values of DO (negatively) separated sites L and M from the others. Site L still formed an intermediate group between $\mathrm{M}$ and the other sites.

Although it had a low explicability value, axis 2 revealed a clear separation among seasonal periods (Summer, Spring/Autumn, and Winter),

Table 2. Correlation and performance values obtained through Principal Component Analysis (PCA) to Descoberto River Basin from March/2003 to April/2004.

\begin{tabular}{lcc}
\hline \multicolumn{1}{c}{ Parameters } & Axis 1 correlation & Axis 2 correlation \\
\hline Water temperature & 0.6081 & 0.4570 \\
pH & 0.6696 & -0.0498 \\
Turbidity & 0.6772 & 0.5434 \\
Conductivity & 0.9014 & -0.0911 \\
Dissolved oxygen concentration & -0.9276 & 0.1770 \\
Biochemical oxygen concentration & 0.9107 & 0.0039 \\
Total phosphorus & 0.9046 & -0.2509 \\
Orthophosphate & 0.8068 & -0.1843 \\
Ammonium ions & 0.7838 & 0.1112 \\
Nitrate & 0.7158 & -0.4289 \\
Nitrite & 0.5782 & 0.2352 \\
Chloride & 0.9666 & -0.0428 \\
Fecal coliforms & 0.8978 & 0.0587 \\
Chlorophyll & 0.9444 & 0.0566 \\
Total organic carbon & 0.9048 & -0.0467 \\
Rainfall & 0.0724 & 0.9275 \\
Eigenvalue & 10.165 & 1.766 \\
\% variance & 63.534 & 11.036 \\
Broken-stick & 3.381 & 2.381 \\
\hline
\end{tabular}


showing more homogeneous groups, especially in Winter. However, during Summer there was a separation between sampling sites from upstream of the reservoir (A to $G$, solid circles) and from

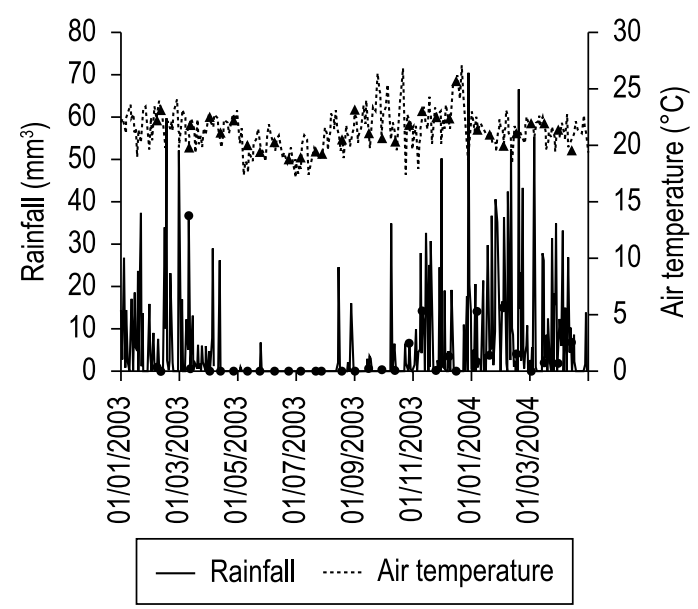

Figure 2. Rainfall and air temperature on Descoberto River Basin from between March/2003 and April/2004 (The matched points indicate the exactly values of rainfall and air temperature in date sampling of the another variables) downstream of the reservoir, where they were more influenced by chemical and biological variables (Figure 5).

The relationship between physical and chemical parameters and biological parameters, through the Spearman Correlation, indicated that chlorophyll-a was influenced positively by water temperature, $\mathrm{pH}$, electrical conductivity, turbidity, total suspended solid, ammonium ions, nitrate, and nitrite (Table 3). BOD5 was directly correlated with turbidity, total suspended solid and total phosphorus. Fecal coliforms correlated with values of $\mathrm{pH}$, turbidity, suspended solid, conductivity, nitrate, and nitrite, while total coliforms correlated with water temperature, $\mathrm{pH}$, turbidity, total suspended solid, conductivity, total phosphorus, and nitrate (Table 3).

\subsection{Spatial and temporal continuity}

The sites that showed differences in the largest number of parameters, among the 16 analyzed, were $\mathrm{K}$ and L (Table 4), always with highest values for site L, except DO (Figure 4). The sites A and C;

Table 3. Spearman correlation among biotic and abiotic variables $(\mathrm{p}<0.05)$.

\begin{tabular}{lcccccccccc}
\hline & WT & $\mathrm{pH}$ & $\mathrm{TB}$ & $\mathrm{CD}$ & $\mathrm{DO}$ & $\mathrm{TP}$ & $\mathrm{AM}$ & $\mathrm{NTA}$ & NTI & TDS \\
\hline TTC & 0.676 & 0.604 & 0.769 & 0.852 & -0.549 & 0.615 & 0.473 & 0.780 & 0.516 & 0.780 \\
FEC & 0.456 & 0.643 & 0.764 & 0.687 & -0.407 & 0.511 & 0.500 & 0.676 & 0.560 & 0.615 \\
CLP & 0.852 & 0.923 & 0.665 & 0.846 & -0.291 & 0.505 & 0.742 & 0.665 & 0.747 & 0.681 \\
BOD $_{5}$ & 0.104 & 0.357 & 0.753 & 0.253 & -0.346 & 0.692 & 0.319 & 0.418 & 0.445 & 0.698 \\
\hline
\end{tabular}

WT - water temperature; TB - turbidity; CD - conductivity; DO - dissolved oxygen concentration; TP - total phosphorus; NTA - nitrate; NTI - nitrite; AM - ammonium ions; TDS - total suspended solids; CLP - Chlorophyll; BOD5- biochemical oxygen dissolved; FEC - fecal coliforms; TTC - total coliforms.

Table 4. Comparison of the spacial series along 13 sampling site of the Descoberto River Basin through KruskalWallis/Dunn test using physical, chemical and biological parameters.

\begin{tabular}{|c|c|c|c|c|c|c|c|c|c|c|c|c|c|c|c|c|}
\hline Sites compared & TB & $\mathrm{pH}$ & $C D$ & DO & TP & $\mathrm{OP}$ & NTA & NTI & AM & COD & CLD & TOC & CLP & $\mathrm{BOD}$ & FEC & TTC \\
\hline $\begin{array}{l}\mathrm{A} \times \mathrm{C} ; \mathrm{B} \times \mathrm{C}, \\
\mathrm{I} \times \mathrm{J} ; \mathrm{J} \times \mathrm{K}\end{array}$ & ns & ns & ns & ns & ns & ns & ns & ns & ns & ns & ns & ns & ns & ns & ns & ns \\
\hline CxI & ns & * & * & ns & ns & ns & ns & ns & ns & ns & ns & ns & ns & ns & * & * \\
\hline Dxl & ns & ns & * & ns & ns & ns & * & ns & ns & ns & * & ns & ns & ns & * & * \\
\hline Exl & ns & * & ns & ns & ns & ns & ns & ns & ns & ns & ns & ns & ns & ns & * & ns \\
\hline Fxl & ns & * & ns & ns & ns & ns & ns & ns & ns & ns & ns & ns & ns & ns & ns & ns \\
\hline Gxl & ns & * & * & ns & ns & ns & ns & ns & ns & ns & ns & ns & ns & ns & ns & ns \\
\hline $\mathrm{Hxl}$ & ns & ns & ns & ns & ns & ns & ns & ns & ns & ns & ns & ns & ns & ns & * & ns \\
\hline $\mathrm{KxL}$ & ns & ns & ns & * & * & * & * & * & * & * & * & * & * & * & ns & ns \\
\hline$M x L$ & * & ns & ns & ns & ns & ns & ns & ns & ns & ns & ns & ns & ns & ns & ns & ns \\
\hline
\end{tabular}

TB - turbidity; CD - conductivity; DO - dissolved oxygen concentration; TP - total phosphorus; OP - orthophosphate; NTA - nitrate; NTI - nitrite; AM - ammonium ions; COD - chemical oxygen dissolved; CLD - chloride; TOC - total organic carbon; CLP - Chlorophyll; BOD- biochemical oxygen dissolved; FEC - fecal coliforms; TTC - total coliforms; ${ }^{*} p<0.05$; ns - not significant. 

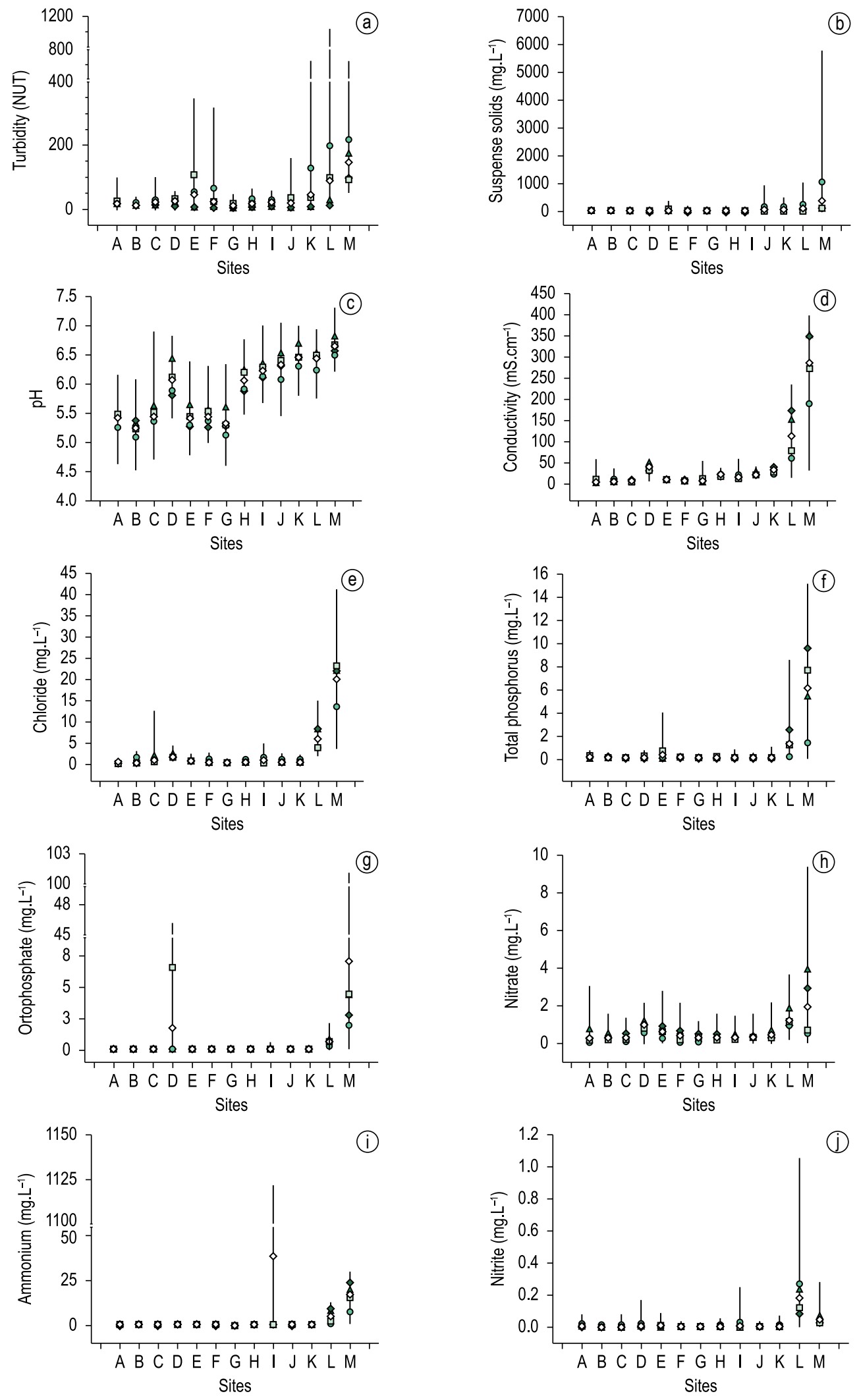

$\diamond$ Winter $\Delta$ Spring $\circ$ Summer $\square$ Autumn $\diamond$ Average

Figure 3. Physical and chemical parameters in Descoberto River Basin from March/2003 to April/2004, a) turbidity; b) suspense solids; c) pH; d) conductivity; e) ions chloride; f) total phosphorus; g) orthophosphate; h) nitrate; i) ammonium; j) nitrite. 


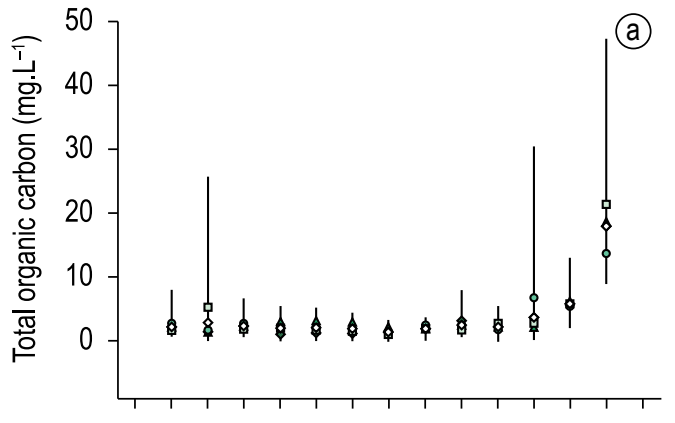

A B C DEF G H J K L M

Sites

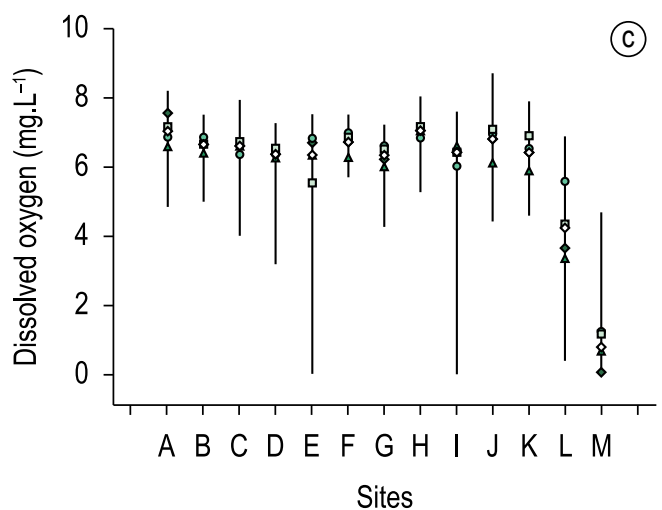

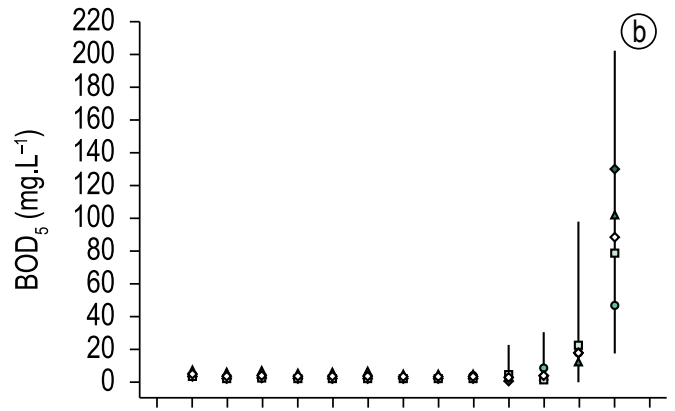

A B C DEF G H I J K L M

Sites

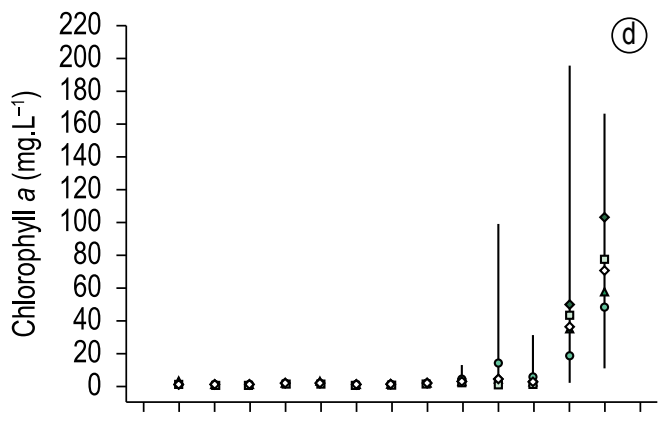

A B C D E F G H I J K L M

Sites

$\diamond$ Winter $\Delta$ Spring $\circ$ Summer $\square$ Autumn $\diamond$ Average

Figure 4. Parameters related with oxygen and chlorophyll in Descoberto River Basin from March/2003 to April/2004, a) chemical oxygen demand; b) biochemical oxygen demand in five days; c) dissolved oxygen concentration; d) chlorophyll.

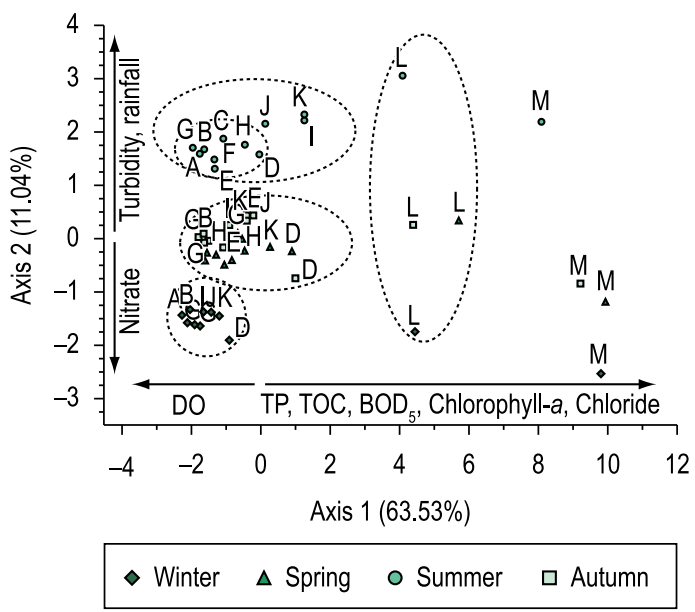

Figure 5. Principal Component Analysis (PCA) for physical, chemical and biological parameters from Descoberto River Basin from March/2003 to April/2004, based on seasonal average (DO - dissolved oxygen concentration; BOD5 - biochemical oxygen demand after five days; TP - total phosphorus concentration; TOC - total organic carbon).
$\mathrm{B}$ and $\mathrm{C}$; I and J; and J and $\mathrm{K}$, did not show any differences among each other.

The diagram in Figure 6 strengthens the data that corroborate the system discontinuity ( $\mathrm{C}$ to $\mathrm{H}$ vs. I, and $\mathrm{K}$ vs. L longitudinal series of sample sites). Temporally, the most parameters showed significant differences in Winter and Spring (Table 5).

\section{Discussion}

The construction of reservoirs for various purposes has changed natural ecosystems in many countries. These reservoirs alter the physical and chemical conditions of lotic systems, which can disrupt the longitudinal gradients along river courses (Ward and Stanford, 1983; Straškraba et al., 1993). In addition, pollution sources also influence the connectivity breakdown (Marques et al., 2003). Both types of human interventions were observed along the Descoberto River basin, mainly at two specific points along the main river. This was shown by physical and chemical parameters analyzed on spatial and temporal scales. 
Table 5. Comparison of the temporal series of the Descoberto River Basin through Kruskal-Wallis/Dunn test using physical, chemical and biological parameters.

\begin{tabular}{lccccccccccccc}
\hline Seasonal compared & TB & TDS & pH & DO & TP & OP & NTA & NTI & COD & CLT & TOC & CLP & DBO \\
\hline Autumn $\times$ Winter & $*$ & $*$ & ns & ns & $*$ & ns & $*$ & $*$ & ns & ns & ns & ns & ns \\
Winter $\times$ Spring & $*$ & ns & $*$ & $*$ & $*$ & ns & ns & ns & ns & $*$ & $*$ & $*$ & $*$ \\
Spring $\times$ Summer & $*$ & $*$ & $*$ & $*$ & $*$ & ns & $*$ & ns & ns & ns & ns & ns & ns \\
Summer $\times$ Autumn & ns & $*$ & ns & ns & $*$ & $*$ & ns & ns & $*$ & $*$ & ns & ns & $*$
\end{tabular}

TB - turbidity; TDS - total dissolved solids; DO - dissolved oxygen concentration; TP - total phosphorus; OP orthophosphate; NTA - nitrate; NTI - nitrite; COD - chemical oxygen dissolved; TOC - total organic carbon; CLP - Chlorophyll; BOD- biochemical oxygen dissolved; ${ }^{*} p<0.05$.

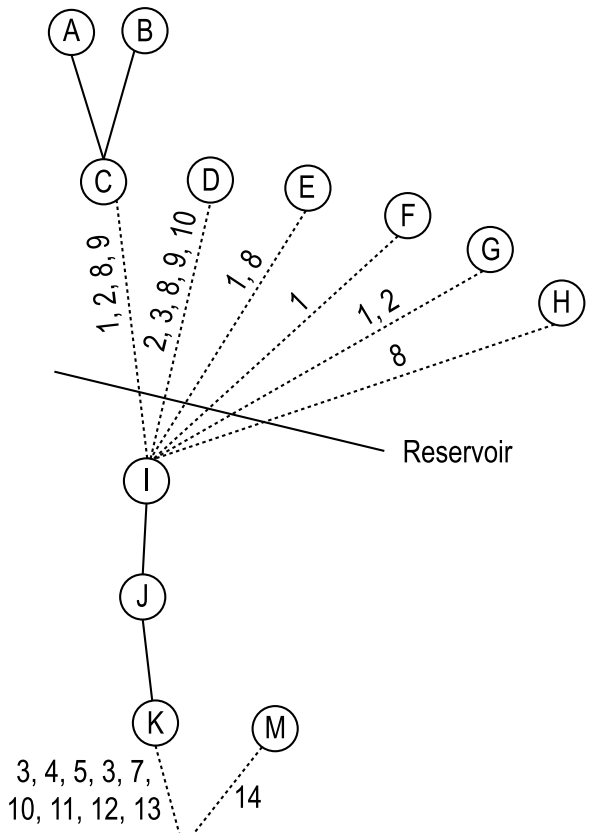

(L)

$$
\begin{aligned}
& \text { - There isn't significant differences } \\
& \text { …. There is significant differences }
\end{aligned}
$$

Figure 6. Diagram representing the Descoberto Basin and its continuum system along the sites $(1: \mathrm{pH} ; 2$ : conductivity; 3 : nitrate; 4 : dissolved oxygen; 5 : chemical oxygen demand; 6: total phosphorus; 7: ammonium; 8: fecal coliforms; 9: total coliforms; 10: ions chloride; 11: total organic carbon; 12 : chlorophyll- $a$; 13: BOD5; 14 : turbidity).

In the Federal District, the winter and summer are seasonal periods most marked, which may be influenced by the hydrological period (dry and rainy). Thus, in the Descoberto River basin, the physical, chemical, and biological variables that influenced the temporal and spatial sampling stations, especially $\mathrm{L}$ and $\mathrm{M}$, were chloride ions, chlorophyll, BOD5, nutrients, TOC, rainfall, and turbidity.
In general, for the Descoberto River basin, lower water temperature coincided with the dry period in winter and autumn, while higher temperatures were related to the rainy season in spring and summer. The highest values for concentrations of nutrients (total phosphorus, orthophosphate, nitrate, and ammonium ions), turbidity, and suspended solids, were probably due to the rainfall, as these events were most marked in the rainy season. This pattern was even more pronounced at stations $\mathrm{M}$ and $\mathrm{L}$. Rainfall, turbidity, nitrate, and water temperature were major factors in the separation between the seasonal periods (Summer, Spring/Autumn, and Winter), with stations A, B, C, D, E, F, H, I, and J forming more homogeneous groups, as in the case of winter.

The longitudinal continuity and spatial proximity of the pairs of stations $\mathrm{A}$ and $\mathrm{C}, \mathrm{B}$ and $\mathrm{C}, \mathrm{I}$ and $\mathrm{J}$, and $\mathrm{J}$ and $\mathrm{K}$ may explain why no differences appeared between them, since the second of each pair receives discharge from the first, thus making the limnological characteristics more homogeneous.

The separation between the sampling stations located upstream (A to $G$ ) versus downstream of the reservoir (I to M), mostly in summer, influenced by biological and chemical variables $(\mathrm{pH}$, electrical conductivity, coliforms, and chloride) were caused by the Descoberto Dam. Status like that have a major impact on the environment downstream, disrupting the system (Marques et al., 2003). Thus, the sampling stations $\mathrm{C}, \mathrm{E}, \mathrm{F}$, and $\mathrm{G}$ differed statistically in terms of $\mathrm{pH}$ values; stations $\mathrm{C}, \mathrm{D}$, and $\mathrm{G}$ in conductivity; stations $\mathrm{C}, \mathrm{D}, \mathrm{F}$, and $\mathrm{H}$ in fecal coliforms; stations $\mathrm{C}, \mathrm{D}$, and $\mathrm{H}$ in total coliforms; and station $\mathrm{D}$ in chloride values, with respect to station I. Reservoirs provide numerous benefits (water supply for hydroelectricity, irrigation, public water supply, navigation), but they affect the rivers by changing the flow and the terrestrial and aquatic system (Tundisi, 2003), manly downstream. 
Among the abiotic variables used to analyze water quality, COD, BOD5, and TOC are key in the degree of pollution. TOC is used for analysis of organic compounds; BOD5 is a measure of the biodegradability of pollutants; and COD is a measure of the total pollution, usually caused by sewage (Kim et al., 2001). Chlorides are largely related to pollution by domestic and industrial sewage (CETESB, 2005), and are therefore another important variable in measuring the degree of pollution. An increase in chloride content in water is an indicator of possible contamination by sewage or industrial waste, and can change water taste and interfere with the analysis of other parameters such as COD (Ayres and Westcot, 1999). The highest values of $\mathrm{COD}, \mathrm{BOD} 5$, and TOC found at stations $\mathrm{M}$ and $\mathrm{L}$ of the Descoberto System indicate that these stations were the most susceptible to the human impacts. Thereby, this resource would be inappropriate to use close the stations $M$ and L. Deforestation, construction of canals and waterways, overfishing, and intensive farming also impact the aquatic systems of central-western Brazil (Tundisi, 2003).

Lateral contributions from tributaries can be a major factor of input of nutrients and transported solids, and thus a major cause of eutrophication, especially if these tributaries are polluted. This occur in Descoberto Basin where the station L was more influenced by station $M$ (i.e. a polluted tributary) than the river channel. The natural regime to the downstream of reservoirs are completely modified since are controlled by anthropogenic means, as the operation of dam that altered water level fluctuation and periodicity of the hydrological regime (Agostinho et al., 2004). This, closely with uncontrolled occupation of the riverbanks, can increase the sewage load and therefore the amount of organic carbon in aquatic systems as well as change in phosphorus concentration, electrical conductivity, BOD5, chlorophyll, and suspended solids (Daniel et al., 2002; Marques et al., 2003). Such features as the fragility and impact on the system were found for the Descoberto River Basin by Rego (1997) and confirmed by our studies, when the station $\mathrm{L}$, which directly receives the discharge from the Melchior tributary influenced by population that increase the sewage load caused um great impact in stations downs.

Although the Descoberto Basin is situated in a Cerrado (savanna) region where nutrient-poor soils predominate (Gomes et al., 2004), some stretches of this basin receive high nutrient loads. This can be confirmed by the results of nutrients, chlorophyll- $a$, turbidity, and BOD5 observed at sites L and M.

Considering the pairs of stations, in general, the system was discontinuous. The sites that showed the largest differences were $\mathrm{K}$ and $\mathrm{L}$, with highest values at site $\mathrm{L}$. The explanation of why site $\mathrm{L}$ was an intermediate group between $\mathrm{M}$ and other sites may be related to its location where it received the entire load originating from upstream and downstream sites of the Descoberto Reservoir and the entire discharge of site M, i.e., the Melchior River. It was expected that the site L would behave similarly to the other sites located upstream (i.e. sites I, J, and $\mathrm{K})$. However, site $\mathrm{L}$ tended to be more similar to $\mathrm{M}$, which was located in a receptor tributary of four urban centers (Águas Claras, Ceilândia, Samambaia, and Taguatinga) and consequently more impacted. Thus, site $\mathrm{M}$ constituted a discontinuity factor according to the serial discontinuity factors concept (Ward, 1998).

Therefore, the system was discontinuous, because of two factors: the Descoberto Reservoir and the input from the Melchior River, an impacted environment by sewage. On the longitudinal axis of the Descoberto Basin, important changes in water quality occur, mainly in the lower portion and especially downstream from Descoberto Dam, with significant increases in nutrient concentrations, suspended solids, turbidity, and chlorophyll and, consequently, decreased water transparency. This change is still more distinct at site $\mathrm{L}$, which receives discharges from the Melchior tributary. In the Melchior Basin, the area of greatest demographic density, the river is highly impacted, receiving domestic and hospital wastes. Thus, eutrophic conditions increase because of the lateral inputs received directly or from the tributary.

\section{Acknowledgements}

We thank Dr. Sérgio Koide and his staff for assistance with sampling and other considerations. We also thank Instituto Nacional de Meteorologia for providing meteorological data and Dr. Janet W. Reid by translation and revision manuscript into English.

\section{References}

AGOSTINHO, AA., THOMAZ, SM. and GOMES, LC. 2004. Threats for biodiversity in the floodplain of the Upper Paraná River: effects of hydrological regulation by dams. Ecohydrology \& Hydrobiology, vol. 4, no. 3, p. 255-268. 
American Public Health Association - APHA. Standard methods for the examination of water and wastewater. 19th ed. Washington, D.C.: American Public Health Association. 1155 p.

ARAÚJO, FG., PINTO, BCT. and TEIXEIRA, TP. 2009. Longitudinal patterns of fish assemblages in a large tropical river in southeastern Brazil: evaluating environmental influences and some concepts in river ecology. Hydrobiologia, vol. 618, p. 89-107.

AYRES M., AYRES Jr., M., AYRES, DL. and SANTOS, AS. 2007. BioEstat 5.0, aplicaçôes estatisticas nas áreas das ciências biológicas e médicas. Belém: Sociedade Civil de Mamirauá.

AYRES, RS. and WESTCOT, DW. 1999. A qualidade da água na agricultura. 2. ed. Campina Grande: UFPB. 218 p.

BAKER, MA., VALETT, HM. and DAHM, CN. 2000. Organic carbon supply and metabolism in a shallow groundwater ecosystem. Ecology, vol. 81, p. 3133-3148.

BRITO, FA. 1999. Gestão ambiental por resultados para a APA do Rio Descoberto. Brasília: Universidade de Brasília - UnB. [Dissertação de Mestrado em Desenvolvimento Sustentável].

CARDOSO, ER. 2002. Fatores influenciando o uso da água para irrigação na bacia do lago Descoberto no DF. Brasília: Universidade de Brasília - UnB. [Dissertação de Mestrado em Tecnologia Ambiental e Recursos Hídricos].

CARMO, MS., BOAVENTURA, GR. and OLIVEIRA, EC. 2005. Geoquímica das águas da bacia Hidrográfica do rio Descoberto, Brasília/DF - Brasil. Quimica Nova, vol. 28, p. 565-574.

CARMOUZE, JP. 1994. O metabolismo dos ecossistemas aquáticos: fundamentos teóricos, métodos de estudo e análises químicas. São Paulo: Edgard Blücher. $253 \mathrm{p}$.

Companhia de Desenvolvimento do Planalto CODEPLAN. 1984. Atlas do Distrito Federal. Brasília: CODEPLAN. vol. II.

Companhia de Tecnologia de Saneamento Ambiental - CETESB. 2005. Relatório de qualidade das águas interiores do estado de São Paulo - 2004. São Paulo: Companhia de Tecnologia de Saneamento Ambiental.

CUSHING, CE., McINTIRE, CD., CUMMINGS, KW., MINSHALL, GW. and PETERSEN, RC. 1983. Relationships among chemical, physical, and biological indices along river continua based on multivariate analyses. Archive für Hydrobiologie, vol. 98, p. 317-326.

DANIEL, MHB., MONTEBELO, AA., BERNARDES, MC., OMETTO, JPHB., CAMARGO, PB., KRUSCHE, AV., BALLESTER, MV., VICTORIA, RL. and MARTINELLI, LA. 2002. Effects of urban sewage on dissolved oxygen, dissolved inorganic and organic carbon, and electrical conductivity of small streams along a gradient of urbanization in the Piracicaba River Basin. Water, Air and Soil Pollution, vol. 136, p. 189-206.

DOI, H. 2009. Spatial patterns of autochthonous and allochthonous resources in aquatic food webs. Population Ecology, vol. 51, p. 57-64.

FALCOMER, J. 2001. Alteraçôes do uso da terra na bacia do Ribeirão Rodeador: área de proteção ambiental (APA) da bacia do rio Descoberto - DF - GO, no período de 1965 a 1991. Brasília: IBAMA. vol. 40, $54 \mathrm{p}$.

GOMES, JBV., CURI, N., MOTTA, PEF, KER, JC., MARQUES, JJGSM. and SCHULZE, DG. 2004. Análise de componentes principais de atributos físicos, químicos e mineralógicos de solos do bioma Cerrado. Revista Brasileira de Ciências do Solo, vol. 28, p. 137-153.

HOMEWOOD, JM. and PURDIE, DA. 2004. and SHAW, PJ. Influence of sewage inputs and fish farm effluents on dissolved nitrogen species in a chalk river. Water, Air and Soil Pollution, vol. 4, p. 117-125.

JACKSON, DA. 1993. Stopping rules in principal components analysis: a comparison of heuristical and statistical approaches. Ecology, vol. 74, p. 2204-2214.

JUNK, WJ., BAYLEY, PB. and SPARKS, RE. 1989. The flood pulse concept in river-floodplain systems. Canadian Special Publication of Fisheries and Aquatic Sciences, vol. 106, p. 110-127.

KIM, Y., SASAKI, S., YANO, K., IKEBUKURO, K., HASHIMOTO, K. and KARUBE, I. 2001. Photocatalytic sensor for the determination of chemical oxygen demand using flow injection analysis. Analytica Chimica Acta, vol. 432, p. 59-66.

LORENZ, CM., VAN DIJK, GM., VAN HATTUM, AGM. and COFINO, WP. 1997. Concepts in river ecology: Implications for indicator development. Regulated Rivers: Research \& Management, vol. 13, p. 501-516.

MALMQVIST, B. and RUNDLE, S. 2002. Threats to the running water ecosystems of the world. Environmental Conservation, vol. 29, p. 134-153.

MARQUES, PHC., OLIVEIRA, HT. and MACHADO, EC. 2003. Limnological study of Piraquara River (upper Iguaçu Basin): spatiotemporal variation of physical and chemical variables and watershed zoning. Brazilian Archives of Biology and Technology, vol. 46, p. 383-394.

McCUNE, B. and MEFFORD, M.J. 1997. Multivariate analysis of ecological data. Version 3.0. MjM Software. Oregon: Gleneden Beach.

PARADis, A., ELKINTON, J., HAYHOE, K. and BUONACCORSI, J. 2008. Role of winter temperature and climate change on the survival and future range expansion of the hemlock woolly adelgid 
(Adelges tsugae) in eastern North America. Mitigation and Adaptation Strategies for Global Change, vol. 13, p. 541-554.

REGIER, HA., HOLMES, JA. and PAULY, D. 1990. Influence of temperature changes on aquatic ecosystems: an interpretation of empirical data. Transactions of the American Fisheries Society, vol. 119, p. 374-389.

REGO, MCAM. 1997. Mapeamento geotécnico da porção sul da área de proteção ambiental da bacia do rio Descoberto. Brasília: Universidade de Brasília - UnB. [Dissertação de Mestrado em Geologia].

REICH, PB. and OLEKSYN, J. 2004. Global patterns of plant leaf $\mathrm{N}$ and $\mathrm{P}$ in relation to temperature and latitude. Proceedings of the National Academy of Sciences U.S.A., vol. 101, p. 11001-11006.

RIBEIRO, MO. 2001. Estudo da Poluição e autodepuração nos rios Melchior e Descoberto, na bacia do Descoberto - DF/GO, com o auxilio de modelos matemáticos de simulação de qualidade da água, para estudos de seu comportamento atual e futuro. Brasília: Universidade de Brasília - UnB. [Dissertação de Mestrado em Tecnologia Ambiental e Recursos Hídricos].

SILVA, CR. 2003. Zoneamento ecológico-econômico da região integrada de desenvolvimento do Distrito Federal e entorno. Rio de Janeiro: CPRM/EMBRAPA/SCOMI. vol. 1-3, $324 \mathrm{p}$.

SREEKANTHA, GKV. and RAMACHANDRA, TV. 2008. Nestedness pattern in freshwater fishes of the Western Ghats: an indication of stream islands along riverscapes. Current Science, vol. 95, p. 1707-1714

STANFORD, JA. and WARD, JV. Revisiting the serial discontinuity concept. Regulated Rivers: Research \& Management, 2001, vol. 17, p. 303-310.
Statsoft, Inc. Statistica for Windows (Computer program manual). Oklahoma: Tulsa, 2005.

STRAŠKRABA, M., TUNDISI, JG. and DUNCAN, A. 1993. State-of-the-art of reservoir limnology and water quality management. In STRAŠKRABA, M., TUNDISI, JG. and DUNCAN, A., ed. Comparative reservoir limnology and water quality management. Dordrecht: Kluwer Academic Publishers. p. 213-288.

TUNDISI, JG. 2003. Água no século XXI: enfrentando a escassez. São Carlos: RiMa/IIE. 248 p.

VALADÃO, LT. 1996. Irrigação. In Anais do Seminário de Água no Distrito Federal. Brasília: SEMATEC. p. 56-58.

VANNOTE, RL., MINSHALL, GW., CUMMINS, KW., SEDELL, JR. and CUSHING, CE. 1980. The River Continuum Concept. Canadian Journal of Fisheries and Aquatic Sciences, vol. 37, p. 130-137.

WARD, JV. 1998. Riverine landscapes: biodiversity patterns, disturbance regimes, and aquatic conservation. Biological Conservation, vol. 83, p. 269-278.

WARD, JV. and STANFORD, JA. 1983. The serial discontinuity concept of lotic ecosystems. In FONTAINE III, TDI. and BARTELL, SM., ed. Dynamics of lotic ecosystems. Michigan: Ann Arbor Science. p. 29-42.

WARD, JV. and STANFORD, JA. 1995. The serial discontinuity concept: extending the model to floodplain river. Regulated Rivers: Research \& Management, vol. 10, p. 59-168.

Received: 11 February 2010 Accepted: 09 November 2010 